\title{
AGRESIVITAS PAJAK PADA PERUSAHAAN PERDAGANGAN DI INDONESIA: PROFITABILITAS, CAPITAL INTENSITY, LEVERAGE, DAN UKURAN PERUSAHAAN
}

\author{
Wukir Wijatmoko Legowo \\ Jurusan Akuntansi, Politeknik Keuangan Negara STAN \\ E-mail:wukiwijatmoko@gmail.com \\ Selly Florentina \\ Jurusan Akuntansi, Politeknik Keuangan Negara STAN \\ E-mail: selly.florentina@gmail.com \\ Amrie Firmansyah \\ Jurusan Akuntansi, Politeknik Keuangan Negara STAN \\ E-mail: amrie.firmansyah@gmail.com
}

\begin{abstract}
This study aims to investigate the effect of company size, profitability, leverage, and capital intensity on tax aggressiveness. This study uses a quantitative method using a sample of trading sector companies listed on the Indonesia Stock Exchange from 2014 up to 2018. The sample selection uses a purposive sampling technique with a final sample of 95 observations. Data testing was performed using multiple regression analysis for panel data. The results of this study indicate that company size, profitability, and capital intensity have a positive influence on tax aggressiveness. Meanwhile, leverage has no effect on tax aggressiveness.
\end{abstract}

Keywords: fixed assets, income, taxes, capital structure.

\begin{abstract}
ABSTRAK
Penelitian ini bertujuan untuk menginvestigasi pengaruh ukuran perusahaan, profitabilitas, leverage, dan intensitas modal terhadap agresivitas pajak. Penelitian ini menggunakan metode kuantitatif dengan menggunakan sampel perusahaan sektor perdagangan yang terdaftar di Bursa Efek Indonesia dari tahun 2014 sampai dengan 2018. Pemilihan sampel menggunakan teknik purposive sampling dengan sampel akhir sebanyak 95 observasi. Pengujian data dilakukan dengan menggunakan analisis regresi berganda untuk data panel. Hasil penelitian ini menunjukkan bahwa ukuran perusahaan, profitabilitas, dan intensitas modal berpengaruh positif terhadap agresivitas pajak. Sementara itu, leverage tidak berpengaruh terhadap agresivitas pajak.
\end{abstract}

Kata kunci: aset tetap, keuntungan, pajak, struktur modal. 


\section{PENDAHULUAN}

Dalam rentang waktu delapan tahun, dari tahun 2010-2017, rasio pajak Indonesia tidak pernah melebihi angka $15 \%$, rasio pajak tertinggi dicapai pada tahun 2012 sebesar 14\% (OECD, 2018). Pada tahun 2017, rasio pajak Indonesia adalah sebesar $11,5 \%$, nilai ini di bawah rata-rata negara OECD sebesar $34,2 \%$ dan juga di bawah kawasan LAC (Latin America dan Caribbean) dan Afrika yang masingmasing rata-rata persentasenya adalah $22,8 \%$ dan 18,2\% (CNBCIndonesia, 2019). Bahkan rasio pajak tersebut merupakan rasio pajak terendah dibandingkan dengan negara-negara di kawasan asia pasifik. Berdasarkan data tahun 2007 sampai dengan 2017, tax ratio Indonesia mengalami penurunan sebesar 0,7 persen dari $12,2 \%$ menjadi $11,5 \%$ (detik.com, 2020).

Tahun 2019, DJP menargetkan penerimaan pajak sebesar Rp2.329 triliun. Namun pada kenyataannya, tahun 2019, hanya menargetkan penerimaan pajak sebesar Rp1.577,56 triliun, masih jauh dari Rencana Strategis yang dicanangkan (kemenkeu.go.id, 2020). Target penerimaan yang lebih kecil tidak serta merta membuat DJP lebih mudah dalam merealisasikan penerimaan tersebut, target penerimaan tersebut hanya mampu dicapai sebesar Rp1.332,06 triliun atau 84,44\% dari yang diharapkan, dengan pertumbuhan hanya $1,43 \%$ dari tahun sebelumnya, di mana pada periode yang sama pada tahun 2018, tingkat pertumbuhan mencapai $14.10 \%$ (pajak.go.id, 2020).

Capaian sebesar $84,44 \%$ merupakan kontribusi dari beberapa jenis pajak. Kontribusi paling besar dipengaruhi oleh Pajak Pertambahan Nilai Dalam Negeri (PPN DN) dengan total penerimaan sebesar Rp346,31 triliun atau 26\% dari total penerimaan pajak 2019 (pajak.go.id, 2020). Selanjutnya PPh Pasal 25/29 Badan dan Pajak Pertambahan Nilai Impor (PPN Impor) masing-masing menyumbang Rp256,74 triliun atau 19,28\% dan Rp171,25 triliun atau $12,86 \%$ dari total penerimaan pajak 2019. Ketiga unsur pajak tersebut berkontribusi hampir $60 \%$ dari total penerimaan pajak, tidak hanya pada tahun 2019 tetapi pada setiap tahun (pajak.go.id, 2020).

Ketiga komponen pajak utama dalam penerimaan pajak tersebut merupakan jenis pajak yang melekat dengan wajib pajak badan. Rendahnya penerimaan pajak pada tiga komponen pajak tersebut berpengaruh besar pada total penerimaan pajak setiap tahun. Salah satu faktor yang menyebabkan rendahnya penerimaan pajak tersebut adalah rendahnya kesadaran 
Wajib Pajak. Sejak Reformasi Perpajakan tahun 1983 dilakukan, perpajakan Indonesia menganut sistem selfassessment. Dengan sistem ini, Wajib Pajak diberikan kepercayaan untuk kewajiban perpajakannya sendiri. Sementara itu, otoritas perpajakan di Indonesia hanya mengawasi aktivitas tersebut melalui pengawasan dan penegakan hukum. Namun dalam praktiknya, kepercayaan yang diberikan pemerintah kepada Wajib Pajak dapat berbalik menjadi celah yang digunakan WP untuk melakukan tindakan-tindakan yang menguntungkan dirinya.

Modus yang dilakukan oleh Wajib Pajak tersebut beragam, salah satu di antaranya adalah adanya aliran dana dari pemilik modal. Perusahaan mencatat aliran tersebut sebagai pinjaman perusahaan, bukan modal. Dari timbulnya utang tersebut, perusahaan mencatat adanya beban bunga yang mengurangi laba sehingga menyebabkan perusahaan mengalami kerugian. Praktik seperti itu merupakan salah satu contoh dari praktik pajak yang agresif yang merupakan aktivitas dalam merekayasa laba kena pajak perusahaan melalui perencanaan pajak melalui cara yang legal (tax avoidance) dan ilegal (tax evasion) (Frank et al., 2009).

Diberlakukannya sistem selfassessment di Indonesia, membuat manajemen memiliki kebebasan penuh dalam membuat laporan perpajakannya. Hal tersebut sesuai dengan teori keagenan di mana manajemen telah diberikan hak oleh prinsipal dalam melaksanakan aktivitas perusahaan sehingga keputusan terkait perusahaan berada di tangan manajemen. Hasil penelitian yang dilakukan Frank et al. (2009) menemukan bahwa perusahaan cenderung agresif terhadap laporan keuangan komersial dan juga laporan perpajakannya.

Ada beberapa alasan perusahaan melakukan penghindaran pajak atau cenderung agresif dalam pelaporan pajaknya. Untuk menjaga harga saham perusahaan tetap tinggi, perusahaan selalu menjadikan pencapaian atas laba yang tinggi sebagai tujuan utama mereka, namun untuk kepentingan perpajakan perusahaan menginginkan nilai laba yang rendah (Francis et al., 2014). Hal ini juga sejalan dengan keinginan pemegang saham untuk meminimalkan pembayaran pajak dalam rangka memaksimalkan nilai perusahaan mereka (Hanlon \& Heitzman, 2010).

Beberapa penelitian sudah dilakukan untuk mengetahui pengaruh beberapa faktor dan karakteristik sebuah perusahaan terhadap agresivitas pajak. Penelitian tersebut antara lain membahas indikator yang mempengaruhi agresivitas pajak berupa, ukuran perusahaan (Ann \& 
Manurung (2019); Dewi \& Cynthia (2018); Goh et al. (2019); Hartadinata \& Tjaraka (2013); Junensie et al. (2020); Ramadani \& Hartiyah (2020); Setyoningrum \& Zulaikha (2019); Setyowati et al. (2018); Sugeng et al. (2020); Yanti \& Hartono (2019), leverage (Adisamartha \& Noviari (2015); Andhari \& Sukartha (2017); Andriani \& Fadilah (2019); Fitri \& Munandar (2018); Fitria (2018); Goh et al. (2019); Junensie et al. (2020); Ramadani \& Hartiyah (2020); Savitri \& Rahmawati (2017); Setyoningrum \& Zulaikha (2019); Setyowati et al. (2018); Yanti \& Hartono (2019); Nurhandono \& Firmansyah (2017), profitability (Andhari \& Sukartha (2017); Andriani \& Fadilah (2019); Ann \& Manurung (2019); Fitri \& Munandar (2018); Fitria (2018); Goh et al. (2019); Savitri \& Rahmawati (2017); Setyowati et al. (2018); Yanti \& Hartono (2019), inventory intensity (Adisamartha \& Noviari (2015); Andhari \& Sukartha (2017); Ann \& Manurung (2019); Sugeng et al. (2020), capital intensity (Adisamartha \& Noviari (2015); Savitri \& Rahmawati (2017), Corporate Social Responsibility (Andhari \& Sukartha (2017); Dewi \& Cynthia (2018); Fitri \& Munandar (2018); Goh et al. (2019); Junensie et al. (2020); Ramadani \& Hartiyah (2020); Setyoningrum \&
Zulaikha (2019), likuiditas (Adisamartha \& Noviari (2015); Andriani \& Fadilah (2019); Ann \& Manurung (2019); Dewi \& Cynthia (2018); Indradi (2018); Ramadani \& Hartiyah (2020); Setyowati et al. (2018), manajemen laba (Kusuma \& Firmansyah (2018); Nurhandono \& Firmansyah (2017), kemampuan manajerial (Nurfauzi \& Firmansyah (2018), Set Kesempatan Investasi (Firmansyah \& Bayuaji (2019).

Dalam teori akuntansi positif yang dikemukakan Watts \& Zimmerman (1990), ada tiga hipotesis utama yang sering diuji dalam teori ini, di antara hipotesis tersebut adalah hipotesis utang/ekuitas dan hipotesis biaya politik. Dalam hipotesis tersebut, perusahaan dengan debt/equity ratio yang lebih tinggi cenderung menggunakan metode akuntansi yang meningkatkan pendapatan perusahaan, hal ini akan mempengaruhi profitabilitas perusahaan. Selanjutnya, dalam hipotesis biaya politik, memprediksi bahwa perusahaan besar cenderung menggunakan praktik akuntansi yang akan menurunkan jumlah laba yang dilaporkan dibanding dengan perusahaan kecil, hal ini secara langsung ataupun tidak langsung akan berpengaruh pada profitabilitas perusahaan. Terakhir, kebijakan investasi perusahaan pada aset tetap juga dapat berpengaruh pada profitabilitas perusahaan. Kondisi tersebut terjadi karena 
perusahaan yang memiliki proporsi aset tetap yang besar akan menanggung beban depresiasi yang besar. Selain berpengaruh pada profitabilitas, kebijakan aset tetap perusahaan juga dapat berpengaruh pada ukuran perusahaan jika ditelusuri dari proksi yang digunakan sebagai ukuran perusahaan dan juga dapat berpengaruh terhadap kebijakan utang perusahaan apabila berkaitan dengan keputusan perusahaan untuk memperoleh aset tetap melalui utang atau sumber daya perusahaan selain utang.

Berdasarkan beberapa penelitian yang telah diungkapkan sebelumnya, terdapat perbedaan hasil penelitian terkait pengaruh profitabilitas, capital intensity, leverage, dan ukuran perusahaan terhadap agresivitas pajak. Adanya perbedaan hasil penelitian tersebut yang menjadi salah satu alasan untuk melakukan konfirmasi kembali pengujian beberapa determinan dari agresivitas pajak. Selain itu, Arham et al. (2020) menunjukkan bahwa penelitian terkait tax avoidance/tax aggresiveness di Indonesia sebagian besar berfokus pada sektor manufaktur. Namun seperti yang disampaikan sebelumnya, sektor manufaktur bukan satu-satunya sektor yang berkontribusi besar kepada penerimaan pajak. Sektor perdagangan juga memberikan kontribusi yang cukup besar kepada penerimaan pajak, di mana pada tahun 2019 menyumbang Rp246,85 triliun atau berkontribusi $19,9 \%$ dari total penerimaan pajak, jumlah tersebut membuat sektor perdagangan menjadi sektor dengan kontribusi terbesar setelah sektor manufaktur.

\section{TELAAH LITERATUR}

\section{Teori Akuntansi Positif}

Selama empat dekade terakhir, teori akuntansi positif telah menjadi salah satu program penelitian akuntansi paling berpengaruh (Kabir, 2010). Watts \& Zimmerman (1990) menyatakan bahwa secara jelas terdapat hubungan antara praktik akuntansi yang dipilih perusahaan dengan variabel-variabel lainnya seperti leverage dan ukuran perusahaan dan hubungan-hubungan tersebut konsisten dalam beberapa studi. Pilihan standar akuntansi dapat mempengaruhi baik kenaikan dalam harga saham maupun kenaikan dalam bonus atau insentif secara tidak langsung melalui pajak, prosedur pengaturan apabila perusahaan diatur, biaya politik, informasi biaya produksi dan secara langsung melalui management compensation plan (Watts \& Zimmerman, 1978). Terdapat tiga hipotesis yang paling sering diuji terkait dengan teori akuntansi positif (Watts \& Zimmerman, 1990).

Pertama adalah Bonus Plan Hypothesis, di mana dalam hipotesis ini, manajer sebuah perusahaan yang memiliki skema bonus plan cenderung memilih metode akuntansi untuk meningkatkan 
pendapatan pada periode berjalan. Namun, pengujian terhadap hipotesis tersebut menemukan bahwa hipotesis tersebut tidak berlaku di semua kondisi. Manajer biasanya melakukan dengan memprediksi pendapatan pada suatu periode, apabila dalam suatu periode, diperkirakan pendapatan perusahaan tidak akan memenuhi target untuk mendapatkan bonus, maka manajer akan mengalihkan pendapatan dari periode tersebut ke periode selanjutnya untuk mendapat kepastian bonus pada periode selanjutnya, dan sebaliknya.

\section{Kedua adalah Debt/Equity}

Hypothesis, yang memprediksi manajer perusahaan yang memiliki debt to equity ratio yang lebih tinggi cenderung menggunakan metode akuntansi yang meningkatkan pendapatan perusahaan. Debt to equity ratio mendorong perusahaan untuk melakukan pembatasan debt covenants atau perjanjian yang dibuat untuk melindungi pemberi pinjaman. Perjanjian utang yang ketat erat kaitannya dengan kemungkinan pelanggaran perjanjian tersebut terjadi dan akan menyebabkan biaya dari technical default. Oleh karena itu, manajer akan memilih metode akuntansi yang meningkatkan pendapatan untuk merelaksasi pembatasan utang dan menghindari biaya technical default.
Terakhir, Political Cost Hypothesis memprediksi bahwa perusahaan besar cenderung menggunakan praktik akuntansi yang akan menurunkan jumlah laba yang dilaporkan dibanding dengan perusahaan kecil. Pajak perusahaan merupakan salah satu political cost. Di mana perusahaan paling besar akan dikenakan tarif pajak tertinggi. Namun, tarif pajak efektif hanya mengukur sebagian dari biaya politik perusahaan, karena tarif pajak tidak termasuk biaya atau manfaat politik lainnya seperti regulasi, subsidi pemerintah dan kontrak, kuota dan tarif impor, dan antitrust. Oleh karena itu, perusahaan besar menimbulkan biaya yang lebih besar melalui proses politik hanya akan terjadi apabila diasumsikan bahwa biaya politik selain pajak tidak men-offset komponen biaya politik berupa pajak (Zimmerman, 1983).

$$
\text { Zimmerman (1983) menyatakan }
$$

bahwa apabila dua perusahaan mempunya aset dan kewajiban yang sama, perusahaan yang lebih sukses (contohnya: lebih profitable) memiliki rasio pajak terhadap arus kas operasi lebih besar dari perusahaan lainnya. Ada dua alasan yang konsisten dengan hipotesis biaya politik. Alasan pertama mengasumsikan bahwa tarif pajak yang tinggi adalah komponen dari total biaya politik dari perusahaan dan merupakan akibat dari redistribusi 
kekayaan oleh proses politik. Alasan kedua mengasumsikan bahwa tarif pajak tinggi merupakan proksi dari kesuksesan perusahaan yang mengakibatkan pengawasan dan aturan yang lebih ketat dari pemerintah.

\section{Penelitian}

Terdahulu

dan

Pengembangan Hipotesis

Siegfried (1974) menemukan

bahwa perusahaan yang besar memiliki sumber daya yang cukup untuk melakukan manipulasi, seperti tax planning dan mengatur aktivitas perusahaan untuk mengoptimalkan tax saving. Hal serupa juga dikemukakan Dunbar et al. (2016) yang mengatakan bahwa perusahaan yang lebih besar mungkin mempunyai sumber daya dan kesempatan yang lebih besar untuk terlibat dalam agresivitas pajak.

Dunbar et al. (2016) menyatakan bahwa ukuran perusahaan berkaitan erat dengan agresivitas pajak. Perusahaan yang lebih besar memiliki diskresi beda permanen yang terbesar dan hal tersebut merupakan indikasi dari Tax Planning yang lebih besar (Dunbar et al., 2016). Sementara itu, Delgado et al. (2018) menyatakan bahwa ukuran perusahaan mempunyai pengaruh terhadap Effective Tax Rate, baik pengaruh positif maupun negatif. Hasil penelitian tersebut sejalan dengan hipotesis biaya politik, namun juga sejalan dengan Tax Planning and Political Power Theory. Penelitian yang dilakukan
Hazır (2019) menyatakan bahwa ukuran perusahaan berpengaruh positif terhadap Effective Tax Rate, hasil tersebut menurutnya mengindikasikan bahwa perusahaan yang lebih besar menghadapi beban pajak yang lebih besar, menurutnya hal itu mendukung teori biaya politik.

Penelitian yang dilakukan di Indonesia terkait dengan pengaruh ukuran perusahaan terhadap agresivitas pajak yang dilakukan Wulansari et al. (2020) menyimpulkan bahwa ukuran perusahaan berpengaruh negatif terhadap agresivitas pajak. Perusahaan yang lebih besar akan mendapatkan pengawasan yang lebih ketat dari stakeholders dan akan cenderung mematuhi aturan pemerintah. Ann \& Manurung (2019) juga menyimpulkan bahwa ukuran perusahaan dapat menurunkan agresivitas pajak. Sebagai imbas dari kurang efektifnya perusahaan dalam melakukan manajemen aset dapat menimbulkan biaya pengelolaan aset yang tidak efisien dan menyebabkan rendahnya laba.

Berdasarkan penelitian-penelitian sebelumnya yang telah dilakukan menghasilkan kesimpulan yang berbeda, beberapa penelitian menghasilkan kesimpulan yang sejalan dengan hipotesis biaya politik, sedangkan penelitian lainnya tidak. Oleh karena itu, penelitian ini menduga bahwa perusahaan yang lebih besar seharusnya akan membayar pajak 
yang lebih besar dibandingkan dengan perusahaan lainnya. Namun, hipotesis biaya politik juga menyatakan bahwa perusahaan yang lebih besar akan cenderung berusaha menurunkan laba perusahaan untuk memperkecil biaya politiknya, yang dalam hal ini adalah biaya pajak. Oleh karena itu, hipotesis pertama dalam penelitian ini adalah:

\section{$H_{1}$ : Ukuran perusahaan berpengaruh} positif terhadap agresivitas pajak

Francis et al. (2014) menyatakan bahwa untuk menjaga harga saham perusahaan tetap tinggi, perusahaan selalu menjadikan pencapaian atas laba yang tinggi sebagai tujuan utama mereka, namun untuk kepentingan perpajakan perusahaan menginginkan nilai laba yang rendah. Hal ini juga sejalan dengan keinginan pemegang saham untuk meminimalkan pembayaran pajak dalam rangka memaksimalkan nilai perusahaan mereka (Hanlon \& Slemrod, 2009) Semakin besar laba perusahaan, tentunya pajak yang dibayarkan juga semakin besar. Namun ada kemungkinan perusahaan yang memiliki tingkat profitabilitas yang tinggi, cenderung mempertahankan laba yang tinggi pula untuk menjaga harga saham. Oleh karena itu, perusahaan akan cenderung agresif untuk mengurangi beban pajak. Andhari \& Sukartha (2017) menemukan bahwa profitabilitas berpengaruh positif terhadap agresivitas pajak. Perusahaan yang lebih profitable menunjukkan pengelolaan sumber daya yang efisien sehingga memperoleh tarif pajak efektif yang lebih rendah. Perusahaan tersebut dapat memanfaatkan insentif pajak dan melakukan perencanaan pajaknya dengan baik sehingga dapat menurunkan kewajiban pajak efektifnya. Oleh karena itu, hipotesis kedua dalam penelitian ini adalah:

$\mathrm{H}_{2}$ : Profitabilitas berpengaruh positif terhadap agresivitas pajak

Financial leverage merupakan penggunaan utang sebagai sumber pendanaan pada tingkat pengembalian yang diharapkan perusahaan. Perusahaan akan memutuskan penggunaan utang dalam menambah aset, dengan catatan, pengembalian yang diperoleh melebihi biaya yang dikeluarkan. Financial leverage dapat dikaitkan dengan struktur modal perusahaan.

Gupta \& Newberry menyatakan bahwa keputusan pendanaan perusahaan berpengaruh terhadap effective tax rate karena adanya perbedaan perlakuan perpajakan terhadap utang dan modal. Perusahaan yang lebih banyak menggunakan utang dalam struktur modalnya memiliki ETR yang lebih kecil. Hal ini disebabkan penggunaan utang akan menimbulkan beban bunga yang menurut 
perpajakan merupakan deductible expense, sedangkan pembayaran dividen merupakan non-deductible expense.

Penelitian yang menguji pengaruh leverage terhadap agresivitas pajak yang dilakukan oleh Dunbar et al. (2016) menyatakan bahwa perusahaan yang lebih banyak menggunakan utang dalam struktur modalnya memiliki lebih banyak diskresi beda tetap. Hal ini sejalan dengan Hazır (2019) yang menyatakan bahwa jumlah utang yang lebih besar akan menghasilkan Effective Tax Rate yang lebih rendah. Oleh karena itu, utang menjadi salah satu faktor yang memotivasi perusahaan untuk mengurangi beban pajak.

Wulansari et al. (2020) menemukan bahwa leverage mempunyai pengaruh negatif terhadap agresivitas pajak, pengaruh tersebut diartikan bahwa semakin tinggi leverage sebuah perusahaan maka beban bunga yang ditanggung perusahaan akan semakin besar sehingga akan mengurangi penghasilan kena pajak. Penghasilan kena pajak yang cenderung rendah ini akan mengurangi tingkat agresivitas pajak perusahaan.

Utang merupakan salah satu faktor yang dapat menurunkan jumlah pajak yang dibayarkan. Dengan demikian, penelitian ini menduga bahwa keputusan perusahaan untuk lebih banyak menggunakan utang dalam struktur modalnya merupakan motivasi untuk mengurangi jumlah pajak yang dibayarkan. Oleh karena itu, hipotesis ketiga dalam penelitian ini adalah:

$H_{3}$ : Leverage berpengaruh positif terhadap agresivitas pajak

Keputusan investasi perusahaan dapat mempengaruhi beban pajak yang timbul. Gupta \& Newberry (1997) menyimpulkan bahwa perusahaan yang lebih besar menginvestasikan asetnya dalam bentuk aset tetap akan memiliki effective tax rate yang lebih rendah daripada perusahaan yang lebih banyak menginvestasikan asetnya dalam bentuk inventory. Hasil yang serupa juga ditemukan dalam penelitian Richardson \& Lanis (2007). Kondisi tersebut terjadi karena perusahaan yang memiliki proporsi aset tetap yang besar akan menanggung beban depresiasi yang besar, sedangkan inventory tidak menimbulkan beban depresiasi. Dengan demikian, perusahaan dengan capital-insentive akan memiliki effective tax rate yang rendah. Oleh karena itu, hipotesis keempat yang diajukan dalam penelitian ini adalah:

$H_{4}$ : Capital intensity berpengaruh positif signifikan terhadap agresivitas pajak.

\section{METODOLOGI PENELITIAN}

Penelitian ini menggunakan metode kuantitatif. Objek pada penelitian ini adalah agresivitas pajak. Data yang akan 
digunakan dalam penelitian ini adalah data sekunder yaitu data laporan keuangan perusahaan yang termasuk dalam sektor perdagangan, baik perdagangan eceran maupun perdagangan besar dari tahun 2014 sampai dengan tahun 2018, yang bersumber dari situs resmi Bursa Efek Indonesia (BEI) pada alamat situs https://www.idx.co.id/. Pada penelitian ini, teknik yang digunakan untuk pengambilan sampel adalah teknik purposive sampling. Pemilihan teknik pada penelitian ini karena sampel yang digunakan memerlukan kriteria-kriteria tertentu sebagai berikut:

1. Perusahaan telah terdaftar di BEI sebelum tahun 2012, agar data perusahaan yang akan digunakan memiliki data lengkap laporan keuangan selama 5 tahun dan bukan merupakan wajib pajak yang baru terdaftar, selain itu data tersebut untuk memastikan bahwa perusahaan pada tahun 2014 sampai dengan tahun 2018 sudah tidak melakukan kompensasi kerugian dari tahun sebelumnya;

2. Perusahaan merupakan yang termasuk dalam sektor perdagangan, baik perdagangan besar maupun perdagangan eceran;

3. Perusahaan yang mempunyai peredaran usaha di atas Rp4,8 Milyar dalam setahun, sepanjang tahun 2014 sampai dengan tahun 2018, hal ini dikarenakan perusahaan yang mempunyai peredaran usaha di bawah Rp4,8 Milyar dikenakan jenis pajak yang berbeda;

4. Perusahaan yang tidak mengalami kerugian sepanjang tahun 2014 sampai dengan 2018 dan perusahaan yang sudah tidak melakukan kompensasi kerugian sepanjang tahun 2014 sampai dengan tahun 2018, karena perusahaan yang mengalami kerugian atau melakukan kompensasi kerugian akan secara langsung berdampak pada beban pajak yang dibayarkan;

5. Perusahaan yang mempunyai beban pajak positif pada tahun 2014 sampai dengan tahun 2018 atau perusahaan tidak mempunyai pajak lebih bayar pada tahun tersebut;

6. Perusahaan yang mempunyai data laporan keuangan lengkap dari tahun 2014 sampai dengan tahun 2018.

Variabel dependen dalam penelitian ini adalah agresivitas pajak, sedangkan variabel independen meliputi ukuran perusahaan, profitabilitas, leverage, dan capital intensity. Penelitian yang dilakukan di Indonesia banyak menggunakan basis Effective Tax Rate (ETR) sebagai variabel agresivitas pajak. Dunbar et al. (2016) mengungkapkan 
bahwa semakin tinggi agresivitas pajak perusahaan akan menghasilkan ukuran yang berbasis ETR lebih kecil dan ukuran yang berbasis selain ETR yang semakin besar. Sementara itu, Dyreng et al. (2008) menyebutkan bahwa ETR adalah yang pertama harus dipertimbangkan dalam mengukur agresivitas pajak, karena perusahaan diharuskan untuk mengungkap beban pajaknya dalam laporan keuangan. Tetapi, ETR mempunyai beberapa kelemahan, salah satunya adalah ETR diukur hanya berdasarkan data tahunan dan akan terdapat variasi yang signifikan pada ETR setiap tahunnya. Selain itu, ETR juga tidak mempertimbangkan adanya temporary book-tax difference (beda temporer), hal ini karena beban pajak yang dilaporkan pada laporan keuangan perusahaan mengandung beban pajak kini dan beban pajak tangguhan. Beban pajak tangguhan merupakan hasil dari adanya beda temporer.

Dyreng et al. (2008) melakukan beberapa modifikasi pada perhitungan ETR untuk mengatasi kelemahan tersebut. Salah satunya adalah dengan mengganti ukuran ETR dari beban pajak menjadi pajak yang dibayar oleh perusahaan. Dalam praktiknya, perusahaan tidak mengungkapkan secara eksplisit berapa jumlah pajak yang sebenarnya dibayar, namun perusahaan seharusnya memisahkan berapa jumlah beban pajak kini dan beban pajak tangguhan perusahaan pada suatu periode. Penggunaan beban pajak kini sebagai ukuran ETR dapat menghilangkan kelemahan ETR yang tidak mempertimbangkan adanya beda temporer. Alasan-alasan tersebut menjadi dasar variabel dependen yang akan digunakan dalam penelitian ini, yaitu Current Book Effective Tax Rate sebagaimana Dunbar et al. (2016), yaitu:

CETR $_{\text {it }}=\frac{\text { Current Income Tax Expense }_{\text {it }}}{\text { Pretax Income }}$

Proksi ukuran perusahaan dalam penelitian ini mengikuti Delgado et al. (2018), Dunbar et al. (2016), Dyreng et al. (2008), dan Hazır (2019), yaitu:

$$
S I Z E_{i t}=\log (\text { Total Asset })_{i t}
$$

Profitabilitas dapat dianggap sebagai hubungan antara pendapatan dan biaya yang timbul dari penggunaan aset, baik aset lancar maupun aset tidak lancar, dalam aktivitas operasi (Gitman, 2009). Proksi yang digunakan untuk mengukur profitabilitas dalam penelitian ini mengikuti Delgado et al. (2018), Dunbar et al. (2016), Dyreng et al. (2008), dan Hazır (2019), yaitu:

$$
R_{\text {it }}=\frac{\text { Pretax }_{\text {Income }} \text { it }}{\text { Total Asset }_{i t}}
$$

Leverage merupakan rasio yang 
digunakan untuk mengukur sejauh mana perusahaan dibiayai dengan utang dan mengindikasikan seberapa besar aset yang dimiliki berasal dari modal pinjaman perusahaan (Setyowati et al., 2018). Proksi leverage yang digunakan dalam penelitian ini mengikuti Delgado et al. (2018), Dyreng et al. (2008), Hazir (2019), dan Nurhandono \& Firmansyah (2017), yaitu:

$L E V_{i t}=\frac{\text { Total Debt }_{i t}}{\text { Total Asset }_{\text {it }}}$

Capital intensity sebagai rasio dari nilai bersih dari property, plant, and equipment terhadap total aset, yang keduanya diukur pada nilai buku Gupta \& Newberry (1997). Proksi capital intensity dalam penelitin ini mengikuti Siregar \& Widyawati (2016) yaitu:

CAPINT $_{i t}=\frac{\text { Total Property, Plant, Equipment }}{\text { it }}$

\subsubsection{Model Penelitian}

Model penelitian yang digunakan dalam penelitian ini sebagai berikut:

CETR $_{i t}=\alpha_{i t}+\beta_{1} S I Z E_{i t}+\beta_{2} R_{0 A}+$ $\beta_{3} L E V_{i t}+\beta_{4}$ CAPINT $_{i t}+e$

Dimana:

CETR = Current income tax expense in year t divided by pretax income in year $t$

SIZE $=$ Log of total asset in year $t$

$R O A=$ Pretax income in year $t$ divided by total asset in year $t$
LEV = Total debt in year $t$ divided by total asset in year $t$

CAPINT = Total Property, Plant, and Equipment divided by total asset in year $t$

$$
\begin{array}{ll}
\alpha & =\text { Constants } \\
\beta & =\text { Regression coefficient }
\end{array}
$$

e $\quad=$ Error

\section{HASIL DAN PEMBAHASAN}

Data yang digunakan dalam penelitian ini adalah data laporan keuangan perusahaan sektor perdagangan yang memenuhi kriteria sebagai berikut: 
Tabel 1

Sampel Penelitian

\begin{tabular}{lrc}
\hline \multicolumn{1}{c}{ Kriteria } & Jumlah & Ukuran \\
\hline Perusahaan sektor perdagangan yang terdaftar di BEI & 72 & Perusahaan \\
Perusahaan yang terdaftar di BEI setelah 1 Januari 2014 & $(23)$ & Perusahaan \\
Elemen dan/atau informasi dalam LK tidak lengkap & $(1)$ Perusahaan \\
Perusahaan dengan peredaran usaha < Rp4,8 Milyar dalam & $(3)$ Perusahaan \\
setahun & & \\
Perusahaan yang mengalami kerugian atau melakukan & $(26)$ Perusahaan \\
kompensasi kerugian & \\
Perusahaan dengan beban pajak negatif atau pajak lebih bayar & $(0)$ Perusahaan \\
Total perusahaan yang digunakan dalam sampel penelitian & 19 Perusahaan \\
Jumlah tahun observasi & 5 Tahun \\
Total sampel & 95 Observasi \\
\hline Sumber: da diah
\end{tabular}

Sumber: data diolah

Hasil analisis statistik deskriptif atas penelitian ini adalah sebagai berikut: seluruh variabel yang digunakan pada

Tabel 2

Statistik Deskriptif Variabel

\begin{tabular}{lccccc}
\hline & CETR & SIZE & ROA & LEV & CAPINT \\
\hline Mean & 0.2575 & 12.5122 & 0.1049 & 0.4976 & 0.1929 \\
Median & 0.2573 & 12.6595 & 0.0797 & 0.4770 & 0.2016 \\
Min & 0.0832 & 10.6698 & 0.0174 & 0.1828 & 0.0152 \\
Max & 0.6127 & 14.0655 & 0.5772 & 0.9530 & 0.4270 \\
Std. Dev & 0.0846 & 0.68935 & 0.1023 & 0.1956 & 0.1244 \\
Obs. & 95 & 95 & 95 & 95 & 95 \\
\hline
\end{tabular}

Sumber: data diolah

Analisis statistik deskriptif dari CETR yang merupakan ukuran dari agresivitas pajak perusahaan memberikan hasil bahwa dalam 5 tahun observasi, CETR memiliki mean sebesar 0,257496. Hasil tersebut sedikit lebih besar dari tarif pajak efektif wajib pajak badan di Indonesia, yaitu sebesar $25 \%$. Nilai minimum dan maksimum dari analisis statistik deskriptif CETR menunjukkan angka 0,084609 dan 0,612741. Angka yang cukup jauh dari nilai mean ini dapat terjadi jika perusahaan memiliki beban pajak tangguhan yang cukup besar setiap tahunnya, sehingga pada tahun di mana perusahaan mengakui pajak terutang lebih kecil dari seharusnya akan menghasilkan nilai lebih kecil dari tarif pajak efektif seharusnya dan sebaliknya saat tahun di mana perusahaan akan mengakui kewajiban pajak tangguhan, perusahaan akan menghasilkan nilai CETR lebih tinggi dari tarif pajak efektif.

Hasil analisis statistik deskriptif untuk variabel independen yang digunakan, yaitu leverage, profitabilitas, 
capital intensity dan ukuran perusahaan, menghasilkan nilai mean masing-masing sebesar 0,4976, 0,1049, 0,1929 dan 12,512. Hasil tersebut dapat menunjukkan bahwa secara rata-rata, perusahaan sektor perdagangan menggunakan hampir 50\% utang sebagai modal untuk menjalankan perusahaan. Selain itu, melihat dari hasil analisis statistik deskriptif tersebut juga dapat dikatakan bahwa secara rata-rata, seluruh aset yang dimiliki perusahaan pada sektor perdagangan, mampu menghasilkan laba sebelum pajak sekitar $10 \%$. Berdasarkan hasil tersebut terlihat juga bahwa rata-rata perusahaan pada sektor perdagangan memiliki aset tetap sebesar $10 \%$ dari total aset yang dimilikinya. Hasil analisis statistik deskriptif ukuran perusahaan yang menunjukkan mean sebesar 12,512 dengan nilai minimum dan maksimum masing-masing 10,669 dan 14,065 dapat menunjukkan bahwa ukuran perusahaan pada sektor perdagangan cenderung tidak terlalu besar perbedaannya.

Berikut disajikan hasil pengujian hipotesis dalam penelitian ini:

Tabel 3

Hasil Uji Hipotesis

\begin{tabular}{lccccc}
\hline \multicolumn{1}{c}{ Variabel } & Prediksi & Coef & t-Stat & Prob & \\
\hline SIZE & - & -0.0420 & -1.9945 & 0.0245 & $* *$ \\
ROA & - & -0.1974 & -1.6598 & 0.0502 & $* *$ \\
LEV & - & -0.0421 & -0.6587 & 0.2559 & \\
CAPINT & - & -0.1638 & -1.4909 & 0.0697 & $*$ \\
R $^{2}$ & 0.1080 & & & & \\
Adj R & 0.0683 & & & & \\
F-Stat & 2.7230 & & & & \\
Prob (F-Stat) & 0.0342 & & & &
\end{tabular}

*) signifikansi pada $\alpha=10 \%$

**) signifikansi pada $\alpha=5 \%$

***) signifikansi pada $\alpha=1 \%$

Sumber: data diolah 


\section{Pengaruh ukuran perusahaan terhadap agresivitas pajak}

Hasil pengujian dalam penelitian ini menunjukkan bahwa ukuran perusahaan mempunyai pengaruh positif terhadap agresivitas pajak. Hasil ini sejalan dengan penelitian yang dilakukan Dunbar et al. (2016), Setyoningrum \& Zulaikha (2019), dan Yanti \& Hartono (2019). Hasil ini sejalan dengan Political Cost Hypothesis yang menyatakan bahwa perusahaan besar cenderung menggunakan praktik akuntansi untuk menurunkan jumlah laba yang dilaporkan dibanding dengan perusahaan kecil. Hasil pengujian yang dilakukan menunjukkan bahwa perusahaan yang lebih besar, konsisten dengan nilai CETR yang lebih rendah dari tarif pajak badan efektif di Indonesia, sedangkan perusahaan dengan ukuran yang lebih kecil cenderung memiliki CETR yang lebih tinggi dari tarif pajak badan efektif di Indonesia. Hal tersebut dapat dilihat dari beberapa perusahaan yang memiliki nilai variabel SIZE mendekati nilai maksimum, menghasilkan nilai variabel CETR di bawah rata-rata nilai CETR dari sampel atau di bawah tarif pajak badan efektif di Indonesia, sepanjang periode penelitian.

Sementara itu, untuk perusahaan yang memiliki nilai variabel SIZE di bawah atau mendekati rata-rata sampel, cenderung menghasilkan nilai variabel CETR yang fluktuatif sepanjang periode penelitian, di mana dalam satu periode perusahaan memiliki nilai CETR di bawah rata-rata sampel atau tarif pajak badan efektif dan di periode lainnya perusahaan memiliki nilai CETR lebih tinggi dari ratarata sampel atau tarif pajak badan efektif. Perusahaan yang lebih besar memiliki sumber daya atau kemampuan untuk melakukan perencanaan pajak, sehingga perusahaan yang lebih besar akan lebih memungkinkan untuk memanfaatkan beda permanen untuk menghasilkan beban pajak yang lebih kecil dari seharusnya. Namun, untuk perusahaan yang lebih kecil, perusahaan cenderung memanfaatkan beda temporer untuk menghasilkan beban pajak yang lebih rendah, sehingga pada periode berikutnya akan menghasilkan beban pajak yang lebih besar.

Salah satu contoh sumber daya yang dimiliki oleh perusahaan besar dalam hubungannya dengan agresivitas pajak adalah kemampuan perusahaan untuk melakukan upaya hukum atas pemeriksaan yang dilakukan oleh institusi pajak. Indikasi ini dapat terlihat dalam catatan atas laporan keuangan perusahaan yang dijadikan sampel. Dalam catatan atas laporan keuangan tersebut, banyak didapati perusahaan yang melakukan upaya hukum baik sampai tingkat keberatan maupun sampai tingkat peninjauan kembali.

Perusahaan yang lebih besar 
cenderung memiliki citra yang lebih baik di hadapan institusi pajak, karena biasanya perusahaan-perusahaan besar menyumbang mayoritas pajak yang diterima oleh negara, terlepas dari praktik agresivitas pajak yang mereka lakukan. Sehingga menjadi indikasi pajak yang dibayar oleh perusahaan-perusahaan yang lebih besar dianggap sudah wajar oleh institusi pajak dan berakibat pada lemahnya pengawasan yang dilakukan kepada wajib pajak yang lebih besar.

Hasil pengamatan pada catatan atas laporan keuangan dari perusahaanperusahaan yang dijadikan sampel dalam penelitian ini menunjukkan bahwa sebagian besar perusahaan diterbitkan produk surat ketetapan yang dihasilkan sebagian besar adalah Surat Ketetapan Pajak Lebih Bayar (SKPLB). Banyaknya produk SKPLB yang dihasilkan dari kegiatan pemeriksaan dapat menjadi indikasi tingginya tingkat kepercayaan institusi pajak kepada perusahaan besar. Hal ini juga dapat menjadi indikasi bahwa perusahaan yang besar tidak hanya memiliki cukup sumber daya untuk menghasilkan laporan pajak dengan beban pajak yang lebih kecil dari yang seharusnya, namun juga memiliki sumber daya untuk meyakinkan institusi pajak.

\section{Pengaruh profitabilitas terhadap agresivitas pajak}

Pengujian dalam penelitian ini menunjukkan bahwa profitabilitas memiliki pengaruh positif terhadap agresivitas pajak. Penelitian ini sejalan dengan Dunbar et al. (2016), Andhari \& Sukartha (2017), dan Andriani \& Fadilah (2019). Hasil penelitian ini menunjukkan bahwa perusahaan berhasil memanfaatkan celah koreksi fiskal dari peraturan perundang-undangan yang berlaku. Perusahaan dengan tingkat profitabilitas yang tinggi seharusnya juga memiliki beban pajak yang tinggi dengan tarif pajak yang sama. Namun, dengan kemampuan perusahaan memanfaatkan celah peraturan pajak, perusahaan dapat menghasilkan penghasilan kena pajak yang jauh lebih rendah dari laba sebelum pajaknya.

Perusahaan biasanya memanfaatkan grey area pada peraturan perpajakan yang dapat dijadikan dasar perusahaan untuk mengurangi penghasilan yang didapatkan atau memperbesar beban yang dapat diakui sebagai pengurang pajak. Namun, jika melihat hasil sebaran pada analisis statistik deskriptif, di mana rata-rata perusahaan pada sektor perdagangan memiliki beban pajak yang sama dengan bahkan sedikit melebihi tarif pajak efektif yang berlaku di Indonesia, dapat dikatakan bahwa perusahaan cenderung memanfaatkan beda 
temporer. Perusahaan biasanya memanfaatkan beda temporer untuk mengecilkan beban pajaknya karena mengejar kinerja perusahaan pada suatu periode tertentu, sehingga dengan mengecilkan beban pajak perusahaan dalam periode tersebut, perusahaan dapat menghasilkan laba bersih yang lebih besar dibanding jika perusahaan mencatat beban pajak dengan kondisi sebenarnya.

Profitabilitas secara tidak langsung juga berkaitan dengan variabel lain yang digunakan dalam penelitian ini, yaitu ukuran perusahaan dan capital intesnity. Hal tersebut dapat terlihat dari sampel yang digunakan dalam penelitian ini, di mana perusahaan yang memiliki ukuran di bawah atau mendekati rata-rata sampel, namun memiliki tingkat laba yang lebih tinggi dari perusahaan yang memiliki ukuran hampir sama, akan menghasilkan nilai CETR yang lebih kecil.

Perusahaan mungkin saja memiliki tingkat profitabilitas yang tinggi namun membayar pajak yang lebih rendah. Hal tersebut dapat terjadi karena saat menghitung laba perusahaan mencatat beban depresiasi lebih rendah dari beban depresiasi yang dapat diakui dalam pajak, sehingga perusahaan akan menghasilkan laba yang lebih besar sebagai akibat dari rendahnya beban depresiasi dan beban pajak pada periode tersebut.

\section{Pengaruh leverage terhadap agresivitas pajak}

Hasil pengujian dalam penelitian ini menunjukkan bahwa leverage tidak berpengaruh terhadap agresivitas pajak. Penelitian ini sejalan dengan Goh et al. (2019), Fitri \& Munandar (2018), Yanti \& Hartono (2019), dan Adisamartha \& Noviari (2015), namun tidak sejalan dengan Nurhandono \& Firmansyah (2017). Hasil pengujian ini diduga bahwa sebagian besar utang yang terdapat pada perusahaan sektor perdagangan dalam liabilitas merupakan utang kepada supplier. Utang tersebut timbul dari kegiatan operasi berupa pembelian persediaan yang akan dijual sehingga menghasilkan laba. Utangutang kepada supplier tersebut dikategorikan sebagai utang jangka pendek yang tidak menghasilkan beban bunga bagi perusahaan. Dalam data perusahaan yang dijadikan sampel penelitian, hanya dua perusahaan yang memiliki utang lancar dengan proporsi di bawah $50 \%$ dari total utang perusahaan. Hal ini mengindikasikan bahwa perusahaan pada sektor perdagangan tidak dapat memanfaatkan beban bunga sebagai sarana untuk menurunkan beban pajaknya karena sebagian besar utang yang dimiliki adalah utang lancar yang tidak memiliki beban bunga. Sehingga pada perusahaan sektor perdagangan, tingkat leverage tidak memberikan pengaruh signifikan terhadap 
agresivitas pajak.

Hal ini juga sejalan dengan teori akuntansi positif yang menyatakan bahwa perusahaan dengan tingkat utang yang tinggi cenderung akan menggunakan metode akuntansi dengan tujuan untuk memaksimalkan laba perusahaan. Metode tersebut dipilih karena perusahaan dengan penggunaan utang yang tinggi akan lebih dekat kepada pembatasan debt covenant, yaitu sebuah perjanjian untuk melindungi pemberi pinjaman, sehingga perusahaan akan cenderung memaksimalkan labanya untuk memperlebar pembatasan tersebut (Watts \& Zimmerman, 1990). Hal ini dapat menjadi indikasi pada perusahaan dagang yang sebagian besarnya merupakan utang lancar, di mana perusahaan harus memaksimalkan labanya untuk mendapatkan kepercayaan supplier agar menjual barang kepada perusahaan secara kredit. Metode yang memaksimalkan laba ini akan menyebabkan beban pajak yang harus dibayar meningkat dan tidak diimbangi dengan adanya beban bunga yang dihasilkan dari utang lancar perusahaan, sehingga perusahaan tidak bisa agresif dalam pajak.

\section{Pengaruh capital intensity terhadap agresivitas pajak}

Hasil pengujian dalam penelitian ini menunjukkan bahwa capital intensity memiliki pengaruh positif terhadap agresivitas pajak. Hasil penelitian ini sejalan Andhari \& Sukartha (2017), Fitria (2018) dan Sugeng et al. (2020). Perusahaan yang memiliki porsi aset tetap yang tinggi menanggung beban pajak yang relatif rendah. Hal ini disebabkan oleh adanya peraturan perpajakan yang berlaku di Indonesia yang mengatur beban depresiasi sebagai salah satu biaya yang dapat dikurangkan dalam perhitungan penghasilan kena pajak. Peraturan tersebut memperbolehkan Wajib Pajak untuk menyusutkan semua aset tetap yang dimiliki selama periode tertentu berdasarkan kelompok harta.

Berdasarkan hasil sampel, ditemukan beberapa perusahaan yang memiliki proporsi aset tetap yang kecil dibandingkan dengan total asetnya, menanggung beban pajak kini yang besar, sebagai contoh emiten SDPC. SDPC sepanjang tahun 2014 sampai dengan 2018 memiliki nilai CAPINT berkisar antara 0,016 sampai dengan 0,021. Nilai CAPINT tersebut merupakan nilai yang mendekati nilai minimum dalam penelitian ini. Dengan nilai CAPINT yang rendah tersebut, SDPC menanggung beban pajak kini (CETR) berkisar di angka 0,29 sampai dengan 0,36. Berdasarkan statistik deskriptif, nilai CETR tersebut di atas ratarata data sampel dalam penelitian ini dan lebih tinggi dari tarif pajak efektif yang 
berlaku di Indonesia.

Sebaliknya, perusahaan dengan kode emiten TURI pada tahun 2014 sampai dengan 2018 memiliki nilai intensitas aset tetap yang tinggi, berkisar di antara 0,37 sampai dengan 0,41. Nilai tersebut merupakan nilai CAPINT maksimal dalam penelitian ini. Dengan porsi aset tetap yang hampir mencapai setengah dari seluruh asetnya tersebut, TURI menanggung beban pajak kini yang rendah bahkan di bawah tarif pajak efektif yang berlaku di Indonesia, yaitu berkisar di angka 17\% sampai 20\%. Hal tersebut menandakan bahwa perusahaan yang memiliki aset tetap yang besar berhasil memanfaatkan beban penyusutan untuk melakukan tindakan pajak yang agresif dengan cara mengecilkan beban pajak perusahaan.

Pengaruh positif capital intensity terhadap agresivitas pajak yang dilakukan dengan memanfaatkan beban depresiasi juga dapat dilihat dari catatan atas laporan keuangan perusahaan-perusahaan yang dijadikan sampel. Laporan keuangan perusahaan yang dijadikan sampel menunjukkan bahwa sebagian besar perusahaan memanfaatkan beban depresiasi untuk mengurangi beban pajaknya. Beban depresiasi dapat dijadikan alat perusahaan untuk mengurangi beban pajaknya secara sementara, artinya dalam satu periode perusahaan dapat mengurangi beban pajaknya dengan konsekuensi pada periode selanjutnya perusahaan akan membayar pajak lebih besar karena beban depresiasi sudah diakui perusahaan pada periode sebelumnya.

\section{SIMPULAN}

Penelitian ini menyimpulkan bahwa perusahaan yang semakin besar cenderung memiliki perilaku agresivitas pajak. Perusahaan yang lebih besar biasanya memanfaatkan aset dan sumber dayanya dalam agresivitas pajak, yang dapat ditunjukkan dengan beraninya perusahaan besar mengajukan upaya hukum atas pemeriksaan yang dilakukan oleh otoritas perpajakan di Indonesia. Selain itu, perusahaan yang memiliki keuntungan yang semakin besar cenderung untuk melakukan agresivitas pajak. Tingkat profitabilitas juga terkait dengan metode penyusutan yang dipilih oleh perusahaan dalam menghasilkan laba yang besar namun di sisi lain beban pajaknya rendah. Perusahaan-perusahaan yang memiliki proporsi aset tetap terhadap total aset lebih tinggi, cenderung memiliki beban pajak yang lebih kecil. Perusahaanperusahaan tersebut memanfaatkan beban depresiasi dari aset tetap yang dimiliki tersebut sebagai pengurang penghasilan pajak, yang akan berakibat pada rendahnya beban pajak pada tahun berjalan. Sementara itu, tingkat utang pada perusahaan sektor perdagangan tidak 
memiliki pengaruh terhadap agresivitas pajak disebabkan oleh sebagian besar utang pada perusahaan sektor perdagangan adalah utang kepada supplier. Utang kepada supplier yang termasuk utang jangka pendek menyebabkan perusahaan tidak dapat memanfaatkan beban bunga dari utang sebagai pengurang

Penelitian ini juga memiliki beberapa keterbatasan. Pertama, periode penelitian hanya lima tahun dan sampel yang digunakan hanya 19 perusahaan. Penelitian dengan sampel yang lebih besar dan periode yang lebih panjang akan mengurangi kesalahan statistik. Kedua, variabel agresivitas pajak yang digunakan hanya current effective tax rate. Terdapat banyak variabel lain yang dapat menggambarkan agresivitas pajak, penggunaan lebih dari satu variabel dalam satu penelitian akan lebih menggambarkan agresivitas pajak yang dilakukan perusahaan. Penelitian selanjutnya dapat menggunakan interval waktu yang lebih panjang dalam periode penelitian. Penggunaan periode yang lebih panjang dapat menangkap fenomena terkait pengaruh ukuran perusahaan, profitabilitas, leverage, dan capital intensity terhadap agresivitas pajak secara lebih luas dan komprehensif. Penelitian selanjutnya dapat menggunakan proksi agresivitas pajak lainnya, seperti Effective
Tax Rate (ETR), Cash Effective Tax Rate (CASH_ETR), Book-tax Differences (BTDs), Permanent BTDs (PERM_BTD), Discretionary Permanent BTDs (DTAX), dan Predicted Tax Shelter Firms. pengukuran variabel ukuran perusahaan dengan menggunakan log dari total aset, untuk penelitian selanjutnya dapat menggunakan log dari nilai pasar sebagaimana yang digunakan oleh Ann \& Manurung (2019).

Hasil penelitian ini dapat menjadi pertimbangan bagi Otoritas Perpajakan di Indonesia yaitu Direktorat Jenderal Pajak dalam melakukan pengawasan wajib pajak badan. Direktorat Jenderal Pajak harus lebih serius dalam menangani wajib pajak yang besar dan menambah kapasitas pegawai agar dapat mengimbangi sumber daya yang dimiliki wajib pajak besar, sehingga dapat diketahui dengan jelas kualitas laporan pajak yang disampaikan wajib pajak.

\section{DAFTAR PUSTAKA}

Adisamartha, I. B. P. F., \& Noviari, N. (2015). Pengaruh Likuiditas, Leverage, Intensitas Persediaan Dan Intensitas Aset Tetap Pada Tingkat Agresivitas Wajib Pajak Badan. EJurnal Akuntansi, 13(3), 973-1000.

Andhari, P. A. S., \& Sukartha, I. M. (2017). Pengaruh Pengungkapan Corporate Social Responsibility, Profitabilitas, Inventory Intensity, Capital Intensity Dan Leverage Pada Agresivitas Pajak. E-Jurnal Akuntansi, 18(2017), 2115-2142. 
Andriani, R. N. R., \& Fadilah, A. R. (2019). Pengaruh Return on Asset (ROA), Current Ratio (CR), Debt To Asset Ratio (DAR), Dan Capital Intensity Ratio (CIR) Terhadap Agresivitas Pajak. Jurnal Akuntansi, $14,46-59$.

Ann, S., \& Manurung, A. H. (2019). The Influence of Liquidity,Profitability,Intensity Inventory,Related Party Debt,And Company Size To Aggressive Tax Rate. Archives of Business Research, 7(3), 105-115. https://doi.org/10.14738/abr.73.6319

Arham, A., Firmansyah, A., Nor, A. M. E., \& Vito, B. (2020). A Bibliographic Study on Tax Avoidance Research in Indonesia. International Journal of Psychosocial Rhabilitation, 24(07), 9526-9554.

Beigi, M. R., Rafat, B., \& Panah, H. M. (2013). The analysis of the effect of tax on profitability indices in listed companies of Tehran Stock Exchange. European Online Journal of Natural and Social Sciences, 2(3), 86-98.

Bonaccorsi, A. (1992). ON THE RELATIONSHIP BETWEEN FIRM SIZE AND EXPORT INTENSITY. Journal of International Business Studies, 23, 605-635.

Chen, S., Chen, X., \& Shevlin, T. (2010). Institutional Knowledge at Singapore Management University Are Family Firms more Tax Aggressive than Non-family Firms? Are family firms more tax aggressive than non-family firms? * University of Texas at Austin University of WisconsinMadison. Journal of Financial Economics, 95(1), 41-61.

Dang, C., (Frank) Li, Z., \& Yang, C. (2018). Measuring firm size in empirical corporate finance. Journal of Banking and Finance. https://doi.org/10.1016/j.jbankfin.201 7.09.006

Darmadi, I. N. H., \& Zulaikha. (2013). Analisis Faktor Yang Mempengaruhi Manajemen Pajak Dengan Indikator Tarif Pajak Efektif. Diponegoro Journal of Accounting, 2(4), 1-12.

Delgado, F. J., Fernández-Rodríguez, E., \& Martínez-Arias, A. (2018). Corporation effective tax rates and company size: evidence from Germany. Economic ResearchEkonomska Istrazivanja , 31(1), 2081-2099.

https://doi.org/10.1080/1331677X.20 18.1543056

Dewi, S. P., \& Cynthia, C. (2018). Aggressiveness Tax in Indonesia. Jurnal Akuntansi, 22(2), 239. https://doi.org/10.24912/ja.v22i2.350

Dunbar, A., Higgins, D. M., Phillips, J. D., Plesko, G. A., Dunbar, A., Higgins, D. M., Phillips, J. D., \& Plesko, G. A. (2016). What Do Measures of Tax Aggressiveness Measure? Introduction. National Tax Association, 103.

Dyreng, S. D., Hanlon, M., \& Maydew, E. L. (2008). Long-run corporate tax avoidance. Accounting Review, 83(1), 61-82. https://doi.org/10.2308/accr.2008.83. 1.61

Fitri, R. A., \& Munandar, A. (2018). The Effect of Corporate Social Responsibility, Profitability, and Leverage toward Tax Aggressiveness with Size of Company as Moderating Variable. Binus Business Review, 9(1), 63. https://doi.org/10.21512/bbr.v9i1.367 2

Firmansyah, A., \& Bayuaji, R. (2019). Financial constraints, investment opportunity set, financial reporting aggressiveness, tax aggressiveness: 
evidence from indonesia manufacturing companies. Academy of Accounting and Financial Studies Journal, 23 (5), 1-18

Fitria, E. F. (2018). Pengaruh Capital Intensity, Inventory Intensity, Profitabilitas dan Leverage Terhadap Agresivitas Pajak. Seminar Mahasiswa Nasional Ekonomi Dan Bisnis, 2(1), 1-14. https://doi.org/10.1017/CBO9781107 415324.004

Francis, B., Hasan, I., Wu, Q., \& Yan, M. (2014). Are Female CFOs Less Tax Aggressive? Evidence from Tax Aggressiveness. SSRN Electronic Journal. https://doi.org/10.2139/ssrn.2474543

Frank, M. margaret, Lynch, L. J., \& Rego, S. O. (2009). Tax Reporting Aggressiveness and Its Relation Financial Reporting University of Virginia. Accounting Review, 84(2), 467-496.

Gitman, L. J. (2009). Principles of Managerial Finance (12th ed.). Pearson.

Goh, T. S., Nainggolan, J., \& Sagala, E. (2019). Pengaruh Corporate Social Responsibility, Ukuran Perusahaan, Leverage, dan Profitabilitas terhadap Agresivitas Pajak Perusahaan Pertambangan yang Terdaftar di Bursa Efek Indonesia Tahun 20152018. Jurnal Akuntansi Dan Keuangan Methodist, 3(9), 16891699.

https://doi.org/10.1017/CBO9781107 415324.004

Guenther, D. A., Matsunaga, S. R., \& Williams, B. M. (2013). Tax Avoidance, Tax Aggressiveness, Tax Risk and Firm Risk. https://doi.org/10.1080/00071668.201 2.682724

Gujarati, D. N., \& Porter, D. C. (2009). Basic Econometrics (5th ed.).
McGraw-Hill.

Gupta, S., \& Newberry, K. (1997). Determinants of the variability in corporate effective tax rates: Evidence from longitudinal data. Journal of Accounting and Public Policy. https://doi.org/10.1016/S02784254(96)00055-5

Hanlon, M., \& Heitzman, S. (2010). A review of tax research. Journal of Accounting and Economics, 50(2-3), 127-178.

https://doi.org/10.1016/j.jacceco.2010 .09 .002

Hanlon, M., \& Slemrod, J. (2009). What Does Tax Aggressiveness Signal? Evidence Evidence from Stock Price Reactions to News About Tax Aggressiveness. Journal of Public Economics, 93(1-2), 126-141. https://doi.org/https://doi.org/10.1016 /j.jpubeco.2008.09.004

Hartadinata, O. S., \& Tjaraka, H. (2013). Analisis Pengaruh Kepemilikan Manajerial, Kebijakan Hutang, Dan Ukuran Perusahaan Terhadap Tax Agressiveness. Jurnal Ekonomi Dan Bisnis, 23(3), 48-59.

Hazır, Ç. A. (2019). Determinants of Effective Tax Rates in Turkey. Journal of Research in Business, 1(4), 35-45.

https://doi.org/10.23892/jrb.20194532 93

Helfert, E. A. (2001). Financial Analysis: Tools and Techniques. McGraw-Hill.

Higgins, D., Omer, T. C., \& Phillips, J. D. (2015). The Influence of a Firm's Business Strategy on its Tax Aggressiveness. Contemporary Accounting Research, 32(2), 674702. https://doi.org/10.1111/19113846.12087

Hofstrand, D. (2009). Understanding Profitability. 
Indradi, D. (2018). Pengaruh Likuiditas, Capital Intensity terhadap Agresivitas Pajak (Studi empiris perusahan Manufaktur sub sektor industri dasar dan kimia yang terdaftar di BEI tahun 2012-2016). Jurnal Akuntansi Berkelanjutan Indonesia, 1(1), 147. https://doi.org/10.32493/jabi.v1i1.y20 18.p147-167

Inua, O. . (2018). Determinants of corporate effective tax rates: Empirical evidence from listed manufacturing companies in Nigeria. Accounting and Taxation Review, 2(3), 49-61.

Junensie, P. R., Trisnadewi, A. A. A. E., \& Rini, I. G. A. I. S. R. (2020). Pengaruh Ukuran Perusahaan, Corporate Social Responsibility, Capital Intensity, Leverage dan Komisaris Independen terhadap Agresivitas Pajak Penghasilan Wajib Pajak Badan pada Perusahaan Industri Konsumsi di Bursa Efek Indonesia Tahun 2015 - 2017. Jurnal Ekonomi, Bisnis Dan Akuntansi, 19(2020), 6777.

Kabir, M. H. (2010). Positive Accounting Theory and Science. Journal of CENTRUM Cathedra, 3(2), 136-149. https://doi.org/10.2139/ssrn.1027382

Katz, S. P., Khan, U., \& Schmidt, A. P. (2013). Tax Avoidance and Future Profitability. Columbia Business School Research Paper, 13(10). https://doi.org/10.2139/ssrn.2227149

Kothari, C. R. (2004). Research methodology: methods \& techniques (2nd rev. e). New Age International
(P) Ltd.

Kumar, K. B., Rajan, R. G., \& Zingales, L. (1999). What Determines Firm Size? July. http://www.nber.org/papers/w7208

Kurniasih, T., \& Sari, M. M. R. (2013). Pengaruh Return on Assets, Leverage, Corporate Governance, Ukuran Perusahaan Dan Kompensasi Rugi Fiskal Pada Tax Avoidance. Buletin Studi Ekonomi, 18(1), 58-66.

Kusuma, C. A., \& Firmansyah, A. (2018). Manajemen laba, corporate governance, kualitas auditor eksternal dan agresivitas pajak. Jurnal Telaah Akuntansi dan Bisnis, 8 (1), 108-123.

Novy-Marx, R. (2013). The other side of value: The gross profitability premium. Journal of Financial Economics, 108(1), 1-28. https://doi.org/10.1016/j.jfineco.2013. 01.003

Nugroho, S. A., \& Firmansyah, A. (2018). Pengaruh financial distress, real earnings management dan corporate governance terhadap tax aggressiveness. Journal Of Applied Business Administration, 1 (2), 17-36

Nurfauzi, R., \& Firmansyah, A. (2018). Managerial ability, management compensation, bankruptcy risk, tax aggressiveness. Media Riset Akuntansi, Auditing \& Informasi, 18 (1), 75-100

Nurhandono, F., \& Firmansyah, A. (2017). Pengaruh lindung nilai, financial leverage, dan manajemen laba terhadap agresivitas pajak. Media Riset Akuntansi, Auditing \& Informasi, 17 (1), 31-52

Ramadani, D. C., \& Hartiyah, S. (2020). Pengaruh Corporate Social Responsibility, Leverage, Likuiditas, Ukuran Perusahaan, dan Komisaris (Studi Empiris pada Perusahaan Pertambangan yang Terdaftar di Bursa Efek Indonesia Tahun 2014 
sampai 2018). Journal of Economic, Business and Engineering (JEBE), 1(2), 238-247.

Rego, S. O., \& Wilson, R. (2009). Executive Compensation, Tax Reporting Aggressiveness , and Future Firm Performance. Working Paper, University of Iowa.

Richardson, G., \& Lanis, R. (2007). Determinants of the variability in corporate effective tax rates and tax reform: Evidence from Australia. Journal of Accounting and Public Policy, 26(6), 689-704. https://doi.org/10.1016/j.jaccpubpol.2 007.10 .003

Richardson, G., Taylor, G., \& Lanis, R. (2013). The Impact of Risk Management and Audit Characteristics on Corporate Tax Aggressiveness: An Empirical Analysis. In Journal of Accounting and Public Policy (Vol. 31, Issue 3). https://doi.org/10.1017/CBO9781107 415324.004

Rogers, M. (2004). Networks, firm size and innovation. Small Business Economics, 22(2), 141-153. https://doi.org/10.1023/B:SBEJ.0000 014451.99047 .69

Savitri, D. A. M., \& Rahmawati, I. N. (2017). Pengaruh Leverage, Intensitas Persediaan, Intensitas Aset Tetap, dan Profitabilitas terhadap Agresivitas Pajak. Jurnal Ilmu Manajemen Dan Akuntansi Terapan, 8(November), 64-79.

Schmidt, C. M., \& Zimmermann, K. F. (1991). Work Characteristics, Firm Size and Wages. The Review of Economics and Statistics, 73(4), 705. https://doi.org/10.2307/2109410

Setyoningrum, D., \& Zulaikha. (2019). Pengaruh Corporate Social Responsibility, Ukuran Perusahaan, Leverage, Dan Struktur Kepemilikan Terhadap Agresivitas Pajak.
Diponegoro Journal of Accounting, $8(3), 1-15$.

Setyowati, E., Titisari, K. H., \& Dewi, R. R. (2018). The Effect of Profitability, Leverage, Liquidity, and the Company Size on Aggressiveness Tax the Sector Companies Consumer Goods Industry That Listed On The Indonesia Stock Exchange Year 2014-2016. The 2nd ICTESS 2018, 2018, 374-382.

Siegfried, J. (1974). Effective Average U.S. Corporation Income Tax Rates. National Tax Journal, 27(2), 245-259. Retrieved January 7, 2021, from http://www.jstor.org/stable/41861946

Siregar, R., \& Widyawati, D. (2016). Pengaruh Karakteristik Perusahaan Terhadap Penghindaran Pajak pada Perusahaan Manufaktur di Bei. Jurnal Ilmu \& Riset Akuntansi, 5(2), 24600585.

Sugeng, S., Prasetyo, E., \& Zaman, B. (2020). Does capital intensity, inventory intensity, firm size, firm risk, and political connections affect tax aggressiveness? JEMA: Jurnal Ilmiah Bidang Akuntansi Dan Manajemen, $\quad$ 17(1), 78. https://doi.org/10.31106/jema.v17i1.3 609

Titman, S., Keown, A. J., \& Martin, J. D. (2013). Financial Management: Principles and Application (12th ed.). Pearson.

Watts, R. L., \& Zimmerman, J. L. (1978). Towards a Positive Theory of the Determination of Accounting Standards. The Accounting Review, 53(I), 112-134. http://www.jstor.org/stable/245729\% 0Ahttp://about.jstor.org/terms

Watts, R. L., \& Zimmerman, J. L. (1990). Positive Accounting Theory: A Ten Year Perspective. The Accounting Review, 65(1), 131-156. 
Wulansari, T. A., Titisari, K. H., \& Nurlaela, S. (2020). Pengaruh Leverage, Intensitas Persediaan, Aset Tetap, Ukuran Perusahaan, Komisaris Independen Terhadap Agresivitas Pajak. Jae (Jurnal Akuntansi Dan Ekonomi), 5(1), 69-76. https://doi.org/10.29407/jae.v5i1.141 41

Yanti, L. D., \& Hartono, L. (2019). Effect of Leverage, Profitability and Company Size on Tax Aggressiveness (Empirical Study: Subsector Manufacturing Companies Food, Beverage, Cosmetics and Household Purposes Manufacturing Listed on the Indonesia Stock Exchange for 2014-2017). Journal Budhhi Dharma University, 1(1), 111.

Zimmerman, J. L. (1983). Taxes and Firm Size. Journal of Accounting and Economics, 5(June), 119-149.

https://www.pajak.go.id/id/86-rasio-pajaktax-ratio-dari-masa-ke-masa (diakses April 19, 2020).

https://pajak.go.id/sites/default/files/202002/LAKIN\%20DJP\%202019.pdf (diakses April 23, 2020).

https://www.kemenkeu.go.id/publikasi/berit a/ini-realisasi-penerimaan-negaradi-penghujung-2019/ (diakses April 22, 2020).

https://www.kemenkeu.go.id/publikasi/berit a/mengenal-rasio-pajak-indonesia/ (diakses April 23, 2020).

https://www.cnbcindonesia.com/news/2019 0726094730-4-87743/miristernyata-tax-ratio-indonesiaterendah-di-asia-pasifik (diakses April 22, 2020).

https://finance.detik.com/berita-ekonomibisnis/d-4895226/duh-rasio-pajakturun-jadi-107 (diakses April 22, 2020).

http://www.oecd.org/tax/tax-policy/oecd- classification-taxes-interpretativeguide.pdf (diakses April 23, 2020).

https://www.oecd.org/tax/taxpolicy/revenue-statistics-asia-andpacific-indonesia.pdf (diakses April 23, 2020).

https://www.cnbcindonesia.com/news/2019 0722183208-4-86730/dear-ibu-srimulyani-kenapa-hantu-ini-terusgentayangan (diakses April 22, 2020). 